\title{
Hereditary Meningioma
}

National Cancer Institute

\section{Source}

National Cancer Institute. Hereditary Meningioma. NCI Thesaurus. Code C5301.

A meningioma that is transmitted from the parents to an offspring. 